\title{
3-6 海外のビデオテックス開発動向
}

\section{1. 開 発の背景}

進展する国際的な情報化社会の中で，わが国および欧 米諸国では高度化, 多様化する社会の情報ニーズに応え るため, 近時著しい発達を遂げているエレクトロニクス 技術等を応用した新しい情報メディアの研究開発が活発 に進められている. データ通信, 画像通信, 多重放送, 多目的 CATV 等, その対象は多分野にわたっている が，とりわけビデオテックスについては第 3 の情報革命 といわれるほど画期的なものであり，今後のメディア構 造にあ大きな影響を及ぼすすのと考えられているととか ら, 海外の主要国においてはその早期開発に多大の努力 と熱意が傾注されている.

現在，英国，フランスを初めとするョーロッパ各国が 熱心に取り組んでいるが，乙れはビデオテックスの開発 をててに国内産業経済の振興育成，あるいは情報の有効 的利活用を図りたいといった動機に基づくむのと考えら れる，最近，独自の高級システムを完成したカナダむ同 様である. 一方, 米国ではてれまで目立った動きは見ら れなかった，乙れは，米国ではすでにデータ通信サービ スが広く普及し始めていること, 多様かつ豊富なテレビ 放送が国民の間に根をおろしているとと，民間企業中心 の市場原理が優先されること等の理由によるものと見ら れてきたが, 最近に至って, ビデオテックスの将来性, 有効性等が着目され，各種のプロジェクトが開始され， 大きく動き出そうとしている.

\section{2. 開発の状 況}

各国で開発されているビデオテックスシステムは，そ の方式においてそれぞれ大きな特長を有して和り（表 1 参照)，そのアプリケーションむ多様であるが，乙れま でにないまったく新しい情報メディアを開発し，てれを 実用化させていてうとしている点では共通しているた め, システムの開発を進めているほとんどの国では, 規 模の差はあるあのの実用化任先立ち社会的実験を行うこ とにより, 需要動向, 事業としての可能性, 情報提供体

"3-6 VIDEOTEX in Foreign Countries" by Reiichi Nakano (Ministry of Posts and Telecommunications, Tokyo)

\section{郵政省 中 野 禮一}

制, 既存メディアへのインパクト，技術的諸問題等を確 認し，実用化に臨むという方法をとっている。

海外におけるビデオテックス開発の状況は表 2 に示し た通りであるが，以下に主要国の動向を紹介する.

(a) 英 国

世界最初のビデオテックスシステム“Viewdata”を開 発した英国郵電公社 (BPO) は, 1978 年 6 月から行って きた実験に引き続き，1979 年 3 月 27 日には世界に先駆 けて Prestel の商用サービスを開始した. 商用サービス は，現在，ロンドン，グラスゴー等の 5 地域で提供され ている. 1980 年中にはさらに 13 地域が追加される予定 であるが，乙れにより英国の電話加入者の約 $1 / 2$ がカバ 一される. システムセンターは1つの情報更新センター (UDC) と 2 つ情報検索センター (IRC) から構成され ており,コンピューターハードウェアは GEC 4082 が 使用されている. IRC の情報画面ファイル容量は 25 万 頁であるが，現在蓄積されている画面数は 15 万 6 干頁 となっている．乙れらの情報は 254 の情報提供者から提 供されている. 端末は入力系としてキーパッドまたはキ ーボード，出力系として家庭用テレビ受像機とアダプタ 一あるいは組込み型テレビ受像機から構成されている. 1980 年 4 月 24 日現在の端末数は 3,395 台であるが, こ のうち約 9 割は事業所向けとなっている. BPOでは 1980年末までにこの端末数を数万台にしたい意向を持っ ている. 端末の価格は26インチカラー組込み型の場合, 買取りで約 1,000 ポンド，またレンタルで月額約 25 ポ ンドである. 付加機能としてはテレテキストの受信機 能, オーディオテープインタフェース, ハードコピープ リンター, リモートプログラミング等が実用化されてい る.

ところで BPOは，対内的には商用サービスの早期全 国普及に努力する一方, 対外的にはViewdata システム およびそのソフトウェアの売込みに力を注いでいる. こ のため, 図形表現手段を高度化した Picture Prestel を 初め各種の機能を有した第 2 世代の Prestel の研究開発 を進めている.

(b) フランス

フランスでは郵電省 $(\mathrm{PTT})$ が独自に開発したAntiope 


\section{3. 会話型文字図形情報システム}

表 1 主要ビデオテックスシステムの比較

\begin{tabular}{|c|c|c|c|c|}
\hline システム名 & Prestel & Tetetel & Telidon & CAPTAIN System \\
\hline 名 & 英 & フランス & カ ナ & 本 \\
\hline 伝送方式等 & $\begin{aligned} \text { (伝送力式) } & \text { コード伝送 } \\
\text { (伝 送 路) } & \text { 霞話網 } \\
& \text { 上り } 75 \mathrm{bit} / \mathrm{s} \\
& \text { 下り } 1200 \mathrm{bit} / \mathrm{s}\end{aligned}$ & $\begin{aligned} \text { (伝送方式) コード伝送 } \\
\text { (伝 送 路) 電話網, } \\
\text { Transpac } \\
\text { 上り } 75 \mathrm{bit} / \mathrm{s} \\
\text { 下り } 1200 \mathrm{bit} / \mathrm{s}\end{aligned}$ & $\begin{aligned} & \text { (伝送方式) } \text { コード伝送 } \\
& \text { (伝 送 路) } \text { 電話網, CATV, } \\
& \text { その他 } \\
& \text { 上り } 75 \mathrm{bit} / \mathrm{s} \\
& \text { 下り } 1200 \mathrm{bit} / \mathrm{s}\end{aligned}$ & $\begin{array}{l}\text { (伝送方式) パターン伝送 } \\
\text { (伝 送 路) 電話網 } \\
\text { 上り } 75 \mathrm{bit} / \mathrm{s} \\
\text { 下り } 2400 \mathrm{bit} / \mathrm{s} \\
\text { または } \\
3200 \mathrm{bit} / \mathrm{s}\end{array}$ \\
\hline 端 末 機 & $\begin{array}{c}\text { (入力) キーパッドおよびキ } \\
\text { ーボード } \\
\text { (出力) 家庭用テレビアダプ } \\
\text { ターまたは組込み式 }\end{array}$ & $\begin{array}{l}\text { (大力) キーボード } \\
\text { (出力) 家庭用テレビアダプ } \\
\text { ターまたは組込み式 }\end{array}$ & $\begin{array}{c}\text { (入力) キーパッドおよびキ } \\
\text { ーボード } \\
\text { (出力) 家庭用テレビアダプ } \\
\text { ターまたは組込み式 }\end{array}$ & $\begin{array}{l}\text { (入力) キーパッド } \\
\text { (出力) 家莚用テレビアダプ } \\
\text { ターまたは組込み式 }\end{array}$ \\
\hline $\begin{array}{l}\text { 画面表示能 } \\
\text { 力 }\end{array}$ & 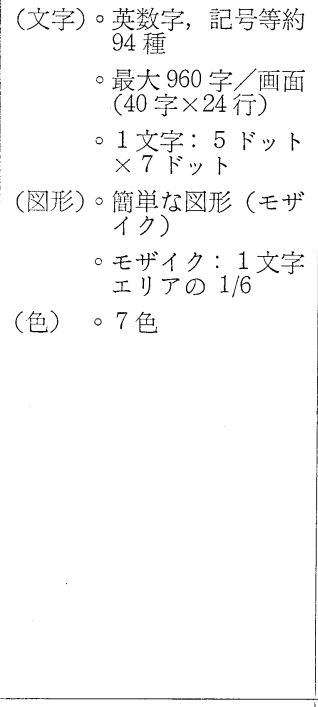 & 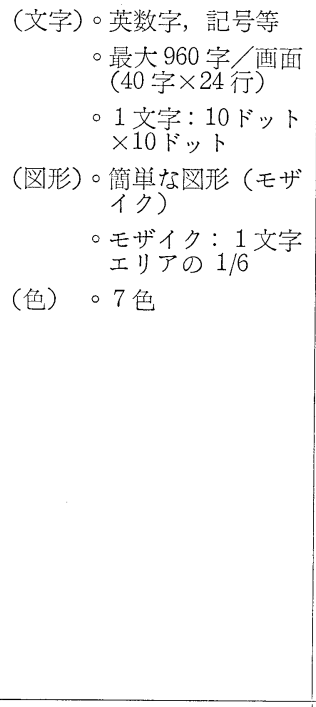 & 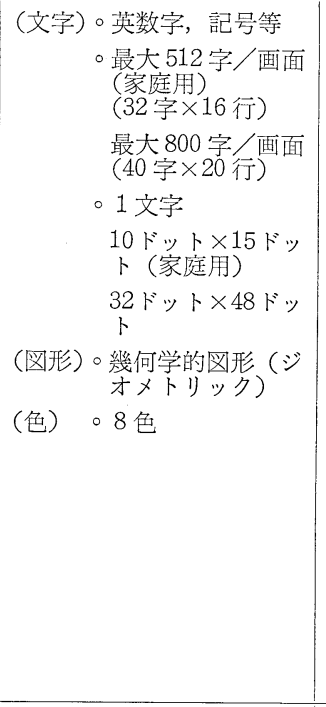 & 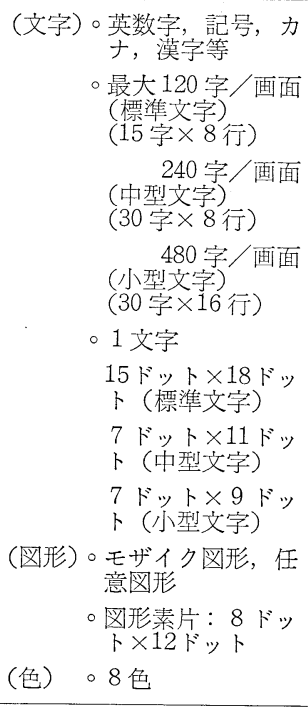 \\
\hline $\begin{array}{l}\text { その他の機 } \\
\text { 能および特 }\end{array}$ & $\begin{array}{l}\text { ○ビデオテックスの原型 } \\
\text { ○テレテキスト受信可 (送 } \\
\text { は不可) } \\
\text { ○オーディオテープとのイ } \\
\text { ンタフェース } \\
\text { ○ハードコピープリンター } \\
\text { ○リモートプログラミング }\end{array}$ & $\begin{array}{l}\text { ○テレテキストとの互換性 } \\
\text { 大 } \\
\text { ○双方向機能大 } \\
\text { ○Antiope 言語 }\end{array}$ & $\begin{array}{l}\text { 。端末の情報センター, 伝 } \\
\text { 送路からの独立 } \\
\text { 。PDI 言語 }\end{array}$ & $\begin{array}{l}\text { ○文字図形表現能力大 } \\
\text { ○伝送誤りに対する耐性大 }\end{array}$ \\
\hline
\end{tabular}

方式による 2つのビデオテックスプロジェクトー“Teletel” 抬よび “Electronic Directory”一を推進してい る.

(1) Teletel 乙れは, ディジタル化された符号化 情報を受けとってパターンに変換しテレビスクリーン上 に映像化する方式技術である Antiope を電話回線に応 用したシステムで, 1980 年末にパリ効外のベリジーの 2,000〜2, 500 世帯の家庭を対象とした実験が開始され る. 実験では, 情報検索サービスの他にメッセージサー ビス，トランザクションサービス（計算，予約，オンラ イン取引等）といった多様なサービスが計画されてお り，乙のため，すべての利用者端末には当初からアルフ アニューメリックキーボードが設置されている。なお，
これらのサービスを提供するサービス提供者数は約 200 社である.

(2) Electronic Directory これは小型のディスプ レイ端末 (7〜9 インチ白黒) にデコーダー，モデムお よびアルファニューメリックキーボードを一体に組み 込んだ利用者端末を利用して，PTT の情報センターに 蓄積されている電話番号リストを検索するシステムで, 近年に打ける電話帳作成コストの急騰，人手による電話 番号案内センターの飽和といった諸事情を考慮し構想さ れたシステムである. この奉験はエレ・エ・ビレヌ地域 で 1981 年末から開始され，1982 年末までにこの地域の 27 万の電話加入者すべてに無償で端末を設置するとと になっている．実験が成功すれば 10 年間で全国にサー 
特 集 $\square$ 文字画像情報システム

表 2 海外におけるビデオテックス開発の状況

\begin{tabular}{|c|c|c|c|c|}
\hline 国名 & 機 関 名 & システム/サービス名 & 開 発 状 沉 & 備 \\
\hline 国 & 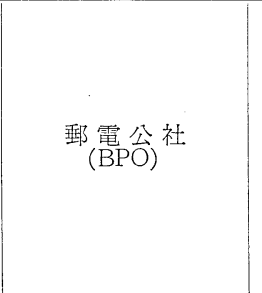 & Prestel & $\begin{array}{l}\text { 1976. } 1 \text { 開発に着手 } \\
\text { 1978. } 6 \text { 実験開始 } \\
\text { 1978. } 3 \text { 商用サービス開始 } \\
\left(\begin{array}{l}\text { 端末数 } 3,395 \text { (家事務所 } 2,972) \\
\text { 情報容量 } 25 \text { 万頁 } \\
\text { 蓄積情報量 } 15 \text { 万 } 6 \text { 千頁 } \\
\text { 情報提供者数 } 254\end{array}\right)\end{array}$ & $\begin{array}{l}\text { ・Viewdata 方式 } \\
\text { ・地域：ロンドン, ノッチンガム, } \\
\text { グラスゴー, エディンバ } \\
\text { ラ, バーミンガム }\end{array}$ \\
\hline $\begin{array}{l}\text { ラ } \\
\text { ン }\end{array}$ & \multirow[t]{2}{*}{$\begin{array}{l}\text { 郵 } \text { 電 省 } \\
(\mathrm{PTT})\end{array}$} & Teletel & $\begin{array}{l}\text { 1976. 秋 開発に着手 } \\
\text { 1980. 末 実験開始予定 } \\
\left(\begin{array}{l}\text { 端末数 家庭 } 2,000 \sim 2,500 \\
\text { 情報容量 } 7 \text { 万千画面 } \\
\text { (外部センタをを除く) } \\
\text { サービス提供者数 150 200 }\end{array}\right)\end{array}$ & $\begin{array}{l}\text { • Antiope 万式 } \\
\text { ・地域：ベリジー }\end{array}$ \\
\hline ス & & Electronic Directory & $\begin{array}{l}\text { 1981. 末 実験開始予定 } \\
\text { 〔端末数 } 27 \text { 万〕 }\end{array}$ & $\begin{array}{l}\text { • Antiope 方式 } \\
\text { ・地域：エレ・エ・ビレヌ } \\
\text { ・端末無償設置 }\end{array}$ \\
\hline \multirow[t]{3}{*}{ 西 } & \multirow{3}{*}{$\begin{array}{l}\text { 郵 }{ }^{\text {電 }} \text { 省 } \\
(\mathrm{BP})\end{array}$} & \multirow{3}{*}{ Bildschirmtext } & $\begin{array}{l}\text { 1976. } 7 \text { 構想を発表 } \\
\text { 1977. } 8 \text { デモンストレーション } \\
\text { 1980. } 6 \text { 実験開始 } \\
\left(\begin{array}{c}\text { 端末娄数 } 3,000 \\
\text { (家庭 } 2,000,1 \mathrm{P} \text { の選定 } 1,000) \\
\text { 情報容量 32万頁 } \\
\text { (外部センター除く) } \\
\text { 情報提供者数 } 350\end{array}\right)\end{array}$ & $\begin{array}{l}\text { ・Viewdata の導入 } \\
\text { ・地域：デェッセルドルフ }\end{array}$ \\
\hline & & & $\begin{array}{l}\text { 1980. 秋 実験開始予定 } \\
\left(\begin{array}{c}\text { 端末数 } 3,000 \\
\text { (家选 } 2,000 \text {, 事業所 } 1,000) \\
\text { 情報容量 } 32 \text { 万頁 } \\
\text { (外部センター除く) } \\
\text { 情報提供者数 デュッセルドルフと } \\
\text { 同じ }\end{array}\right)\end{array}$ & ・地域：ベルリン \\
\hline & & & 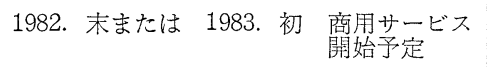 & \\
\hline \multirow{2}{*}{$\begin{array}{l}\text { オ } \\
\text { シ } \\
\text { ダ }\end{array}$} & 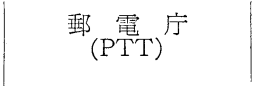 & Viditel & $\begin{array}{c}\text { 1980. } 8 \text { 実験開始予定 } \\
\text { 〔端末数 } 4,000 \text { ? }\end{array}$ & $\begin{array}{l}\text { • Viewdata の導入 } \\
\text { •地域: アムステルダム }\end{array}$ \\
\hline & $\begin{array}{c}\text { オランダ出版グループ } \\
\text { (VNU) }\end{array}$ & TVS & 1980 実験開始予定 & $\begin{array}{l}\text { ・Viewdata の導入 } \\
\text { ・地域：アムステルダム }\end{array}$ \\
\hline $\begin{array}{l}x \\
1 \\
x\end{array}$ & $\begin{array}{l}\text { 郵 } \\
(\mathrm{PTT})\end{array}$ & Viewdata & $\begin{array}{c}1980 \text { 実験開始予定 } \\
\text { 〔端末数 } 100 \text { 〕 }\end{array}$ & $\begin{array}{l}\text { - Viewdata の導入 } \\
\text { • 地域：ベルン }\end{array}$ \\
\hline $\begin{array}{l}7 \\
1 \\
y \\
\bar{y} \\
y \\
F\end{array}$ & $\begin{array}{l}\text { Sanoma Pubishing } \\
\text { Co. } \\
\text { Helsinki } \\
\text { Telephone Co. } \\
\text { Nokia Electronics } \\
\text { Co. }\end{array}$ & Telset & $\begin{array}{l}\text { 1976 } \quad \text { 開発に着手 } \\
\text { 1977. } 3 \text { デモンストレーション } \\
\text { 1978. } 6 \text { 実験開始 } \\
\\
{\left[\begin{array}{l}\text { 端末数 } 100 \\
\text { 蓄積情報量 } 1 \text { 万万画面 }\end{array}\right]}\end{array}$ & •地域 : ヘルシンキ \\
\hline $\begin{array}{l}\text { ス } \\
\dot{n} \\
x \\
1 \\
\text { デ } \\
\text { V }\end{array}$ & $\begin{array}{l}\text { 電気通信庁 } \\
\text { (DGT) }\end{array}$ & Data Vision & 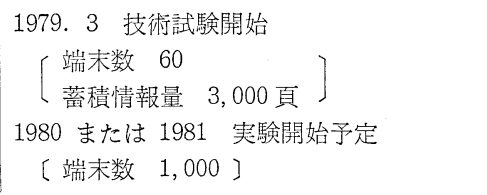 & ・地域：ストックホルム \\
\hline
\end{tabular}


3. 会話型文字図形情報システム

\begin{tabular}{|c|c|c|c|c|}
\hline & 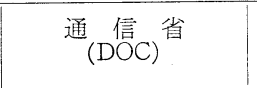 & Telidon & $\begin{array}{l}\text { 1978. } 8 \text { 開発に着手 } \\
\text { 1979. 初 システムの現場試験開始 }\end{array}$ & - Telidon 方式 \\
\hline \multirow{2}{*}{ カ } & $\begin{array}{l}\text { ベルカナダ電話会社 } \\
\text { (Bell Canada) }\end{array}$ & Vista & $\begin{array}{l}\text { 1979. 秋 Telidon 技術導入 } \\
\text { 1980. } 9 \text { 実験開始予定 } \\
\left(\begin{array}{c}\text { 端末数 } 1,000 \\
\text { (家庭 } 800 \text {, 事業所 200) } \\
\text { 情報容量 } 10 \text { 万頁 }\end{array}\right) \\
1981 \text { または } 1982 \text { 商用サービス開始予定 }\end{array}$ & $\begin{array}{l}\text { - Telidon 万式 } \\
\text { ・地域：オタワ,トロント, モン } \\
\text { トリオール }\end{array}$ \\
\hline & $\begin{array}{c}\text { アルバータ州 } \\
\text { 政府電話会社 } \\
\left(\begin{array}{l}\text { Alberta Govern- } \\
\text { ment Telephones }\end{array}\right)\end{array}$ & Vidon & $\begin{array}{l}\text { 1980. } 3 \text { 実験開始 } \\
\text { 〔端末数 } 120 \text { 〕 }\end{array}$ & $\begin{array}{l}\text { - Telidon 方式 } \\
\text { ・地域：カルガリー（アルバータ } \\
\text { 州 })\end{array}$ \\
\hline \multirow{4}{*}{ ナ } & \multirow{3}{*}{$\begin{array}{l}\text { マニトバ電話会社 } \\
\left(\begin{array}{l}\text { Manitoba } \\
\text { Telephone } \\
\text { System }\end{array}\right)\end{array}$} & IDA & $\begin{array}{l}\text { 1980. 初 CATV タイプの実験開始 } \\
\text { 〔端末数 20-100〕 }\end{array}$ & $\begin{array}{l}\text { - Telidon 方式 } \\
\text { ・地域：サウス・ヘッッ゙ィングレ } \\
\text { イ (マニトバ州) }\end{array}$ \\
\hline & & & $\begin{array}{l}\text { 1980. } 6 \text { 電話タイプの実験開始 } \\
\text { 〔端末数 約 } 150 \text { ] }\end{array}$ & $\begin{array}{l}\cdot \text { Telidon 方式 } \\
\text { ・地域：ウィニペグ(マニトバ州) }\end{array}$ \\
\hline & & Elie & $\begin{array}{l}1981 \text { 光ファイバーケーブル使用の実験開 } \\
\text { 始予定 } \\
\text { 〔端末数 } \quad \text { 約 } 150 〕\end{array}$ & $\begin{array}{l}\cdot \text { Telidon 方式 } \\
\text { • 地域 : エリー (マニトバ州) } \\
\text { •DOC, CTCA と共同実験 }\end{array}$ \\
\hline & $\begin{array}{l}\text { グランド・リバー・・ } \\
\text { ケーブル } \\
\text { (Grand River Cable) }\end{array}$ & Grand River & $\begin{array}{l}\text { 1979. } 9 \text { CATV タイプの実験開始予定 } \\
\text { 〔端末数 } 75 \text { 〕 }\end{array}$ & $\begin{array}{l}\text { - Telidon 方式 } \\
\text { ・地域：キッチナー（オンタリオ } \\
\text { 州) }\end{array}$ \\
\hline \multirow[t]{3}{*}{ ダ } & $\begin{array}{l}\text { ブリティィッシュ・コ } \\
\text { ロンビア電話会社 } \\
\left(\begin{array}{l}\text { British Columbia } \\
\text { Telephones }\end{array}\right)\end{array}$ & Vancouver & $\begin{array}{l}1980 \text { 実験開始予定 } \\
\text { 〔端末数 } \\
\text { 約 } 30 \text { 〕 }\end{array}$ & $\begin{array}{l}\cdot \text { Telidon 方式 } \\
\text { ・地域：バンクーバー }\end{array}$ \\
\hline & $\left.\begin{array}{l}\text { ニューブランズウ } \\
\text { イック電話会社 } \\
\text { (New Brunswick } \\
\text { Telephone }\end{array}\right)$ & Mercury & $\begin{array}{l}\text { 1980. 秋 実験開始予定 } \\
\text { 〔端末数 約 } 20 \text { 〕 }\end{array}$ & $\begin{array}{l}\cdot \text { Telidon 方式 } \\
\text { ・地域：ニューブランズウィック }\end{array}$ \\
\hline & $\begin{array}{l}\text { テレケーブル・ } \\
\text { ビデオトロン } \\
\left(\begin{array}{l}\text { Telecable } \\
\text { Videotron }\end{array}\right)\end{array}$ & & $\begin{array}{l}\text { 1981. 初 実験開始予定 } \\
\text { 〔端末数 } 1982 \text { までに約 } 250 \text { 〕 }\end{array}$ & $\begin{array}{l}\text { - Telidon 方式 } \\
\text { ・地域：モントリオール }\end{array}$ \\
\hline \multirow{3}{*}{ 米 } & $\begin{array}{l}\text { 農 } \\
(\mathrm{USD} A)^{\text {務 }}\end{array}$ & Green Thumb Plan & $\begin{array}{l}1976 \text { 研究に着手 } \\
1980 \text { 実験開始 } \\
\text { 〔端末数 農家約 200 〕 }\end{array}$ & $\begin{aligned} \text { ・地域 : ケンタッキー州内の } 2 \\
\text { country }\end{aligned}$ \\
\hline & $\begin{array}{l}\text { ゼ卒ラル電話 } \\
\text { 電子工對会社 } \\
(\mathrm{GTE})\end{array}$ & & $\begin{array}{l}\text { 1980. } 7 \text { 実験開始予定 } \\
\text { 〔端末数 } 400-500 \text { ] }\end{array}$ & - Viewdata の導入 \\
\hline & $\begin{array}{l}\text { アメ寻電話電信会社 } \\
\text { (AT \& }\end{array}$ & $\begin{array}{l}\text { EIS } \\
\left(\begin{array}{l}\text { Electronic Infor- } \\
\text { mation Service }\end{array}\right)\end{array}$ & $\begin{array}{l}\text { 1979. 初 実験準備 } \\
\text { 1979. } 8 \text { 実験開始 } \\
\left(\begin{array}{cc}\text { 端末数 } 20 \\
\text { (家庭 } 12 \text { 事務所 8) } \\
\text { 情報提供者 } 25 \sim 30\end{array}\right) \\
1980 \text { 第 } 2 \text { 実験開始予定 }\end{array}$ & $\begin{array}{c}\text { ・地域: アルバニー（ニューヨー } \\
\text { ク州) }\end{array}$ \\
\hline 国 & $\left.\begin{array}{l}\text { ナイトリッダー } \\
\text { 新聞社 } \\
\text { (Knight Ridder } \\
\text { Newspapers Inc. }\end{array}\right)$ & Viewtron & $\begin{array}{l}\text { 1980. 夏 実験開始予定 } \\
\text { 〔端末数 150-200 〕 }\end{array}$ & $\begin{array}{l}\text { ・地域：コーラル・ゲーブルズ } \\
\text { (フロリダ州) } \\
\text { •実験にはAT \& T む参画 }\end{array}$ \\
\hline
\end{tabular}

ビスを拡大し, 1992 年までに 3,000万台の端末を無償で 設置する計画である。なお，との端末は Teletel サービ スにあ利用できることから，乙のプロジェクトはビデオ テックス普及政策としてもユニークなむので，各国の注 目を集めている. (c) 両独

西独では郵電省 (DBP) がビューデータ技術を基礎と した “Bildschirmtext”を開発した. Bildschirmtextの 実験は市場調查を目的としたものと，技術試験を目的と したものが計画されており，前者は 1980 年 6 月 1 日か 
らデュッセルドルフに扔いて, 後者は 1980 年秋からべ ルリンに抽いて開始される。実験モニターはデュッセル ドルフ, ベルリンとも各 3,000 で, 家庭が主体となって いる。これらのモニターは端末の購入を条件としている が，価格は普通のテレビ受像機と同額とし，デコーダー 等を組込むととによる超過費用は DBP と製造業者が負 担することになっている.

情報画面ファイル容量はデュッセルドルフ, ベルリン と屯に外部センターを除き扔のおの 32 万頁であり，情 報提供者数は 350 社である. DBP では，乙の実験の結 果が満足するものであれば, 1982 年末か 1983 年初には 実用化を図りたいとしている.

(d) カナダ

カナダ通信省 (DOC) の通信研究センターは過去数年 間画像処理に関する研究を行ってきたが，乙の過程でビ デオテックスやテレテキストに応用できる Telidonの開 発に成功した. Telidon 方式はヨーロッパ諸国で採用し ている方式と比較していくつかの優れた特徽を有してい る，例えば，情報センター，伝送路，端末装置それぞれ が独立した構成をとっていることで，乙れはビデオテッ クスを構成する諸技術の変革のテンポがそれぞれ異なる ことに対応してシステムを構成できるように考慮したも のである.

また，画像の表示方式にす大きな特徵がある。すなお ち，乙の方式はビューデータ方式のように走査線でとに 表わすのではなく，画面に表示されている図形を PDI
(Picture Description Instruction)の使用により点, 線, 弧, 面拉よび多角形という幾何学的要素により画像を記 述するむので，優れた解像度とむあいまって，いかなる 種類の図形でむ明確に，精密に描くことができる.

Telidon の実験は, ベルカナダが Vista というサービ ス名でオタワ，トロントおよびモントリオールで 1,000 端末を設置してスタートする他，アルバータ州政府電話 会社，マニトバ電話会社等多くの事業体が実施する計画 であり, また利用する伝送路としても電話回線, CATV, 光ファイバーケーブル, 放送波等, 各種の媒体が利用さ れる.

サービス内容む，情報检索サービスに加えてメッセー ジサービス，トランザクションサービス，音声サービス 等が計画されて抢り，その多様かつ高度なプロジェクト は今後の各国のビデオテックスの展開にも大きな影響を 与えるむのと考朰れ，注目を集めている.

\section{3. 今後の展開}

各国のビデオテックスの技術方式やプロジェクトの内 容，形態等はそれぞれ異なっているが，わが国を含め開 発当事国は，さまざまな形で相互に積極的な開発協力を 行っておう，国際的規模でのビデオテックスの発展に大 きく貢献している．今後はこれらの開発の成果を速やか に国民生活に還元していくことが大きな課題となってお り，てのような観点から新しい情報通信の将来像を形成 していくことが期待されている。（昭和55年7月 2 日受付)

\section{テレビジョン学会誌 11 月号予定目次}

【ふお一かす】

【技 術 解 説】マイクロコンピューターの動向

マイクロコンピューター関連技術の標準化の動向

プログラマブル IC

テレビ受像機へのマイコン応用

【技術の話題】ANTICS—ーアニメーション作成用コンピュータープログラム

【論 文・資 料】ピコ秒ストリークカメラシステムの設計

【これすぼんでんす】CRT ディスプレイにお゙るる動画像用メモリーの構成法とその応用………岡山大 岡本卓爾・藤原 満

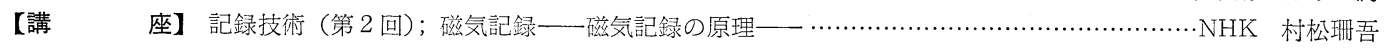

【現場だより】（財）リモートセンシング技術センター………………………リモートセンシングセンター 丸尾啓二

【会議レポート】第 2 回マイクロコンピューター応用国際会議 (IMAC) 報告 ……………………武蔵野通研 野村浩郷 第 8 回国際液晶会議. 